\title{
Effect of Cutting and Intra Row Spacing on Yield and Phenotypical Attributes of Coriander (Coriandrum sativum L.)
}

\author{
Pradip Balaso Bhapkar*, H Dev Sharma, Sudhaker Negi, Diksha Pundir, \\ Vipin Sharma, Monika Kapil and Sridhar Reddy
}

Dr. YS Parmar University of Horticulture \& Forestry, Nauni, Solan (HP) 173230, India

*Corresponding author

\section{A B S T R A C T}

\section{Keywords \\ Cutting, Intra row spacing, Leaf \& seed yield, Coriander \\ Article Info \\ Accepted: \\ 15 August 2019 \\ Available Online: \\ 10 September 2019}

Effect of cutting and intra row spacing on leaf and seed yield of coriander (Coriandrum sativum L) was carried out in cv. Solan Selection at Dr. YSPUHF, Solan (HP) during Rabi 2015. The treatments comprised of three cutting and five intra row spacing. Coriander sown at closer spacing $30 \times 2.5$ $\mathrm{cm}$ and left for seed production after two cuttings (60 \& 75 DAS) gave the highest leaf yield i.e. $55.53 \mathrm{q} \mathrm{ha}^{-1}$ along with seed yield of $17.44 \mathrm{q} \mathrm{ha}^{-1}$ with the maximum B : C ratio (3.39: 1), whereas, sowing at spacing $30 \times 7.5 \mathrm{~cm}$ and taking seed crop after one cutting (60 DAS) gave the highest seed yield i.e. $19.98 \mathrm{q} \mathrm{ha}^{-1}$ along with leaf yield of $13.28 \mathrm{q} \mathrm{ha}^{-1}$ with $\mathrm{B}: \mathrm{C}$ ratio $(2.28: 1)$.

\section{Introduction}

Coriander (Coriandrum sativum L, 2n=22) belongs to the family Apiaceae is an annual herb, mainly cultivated for its fruits as well as for the tender green leaves. Its name has been derived from Greek word "Koris" meaning bad bug because of unpleasant, fetid bug like odour of the green unripened fruits. It is also mentioned in Sanskrit literature and the Bible. It is also recorded that it was the one of the first herbs grown in America by colonizers having been introduced into Massachusedds before 1670 BC (Tiwari and Agarwal, 2014). It is native of South Europe and
Mediterranean region. Globally it is cultivated in India, Malaysia, UAE, Singapore, United Kingdom, South Africa and Indonesia. In India, Rajasthan occupies more area and production among the states followed by Madhya Pradesh, Gujarat, Assam, Andhra Pradesh, Karnataka, Odisha, Tamil Nadu, Uttar Pradesh, Bihar, Chhattisgarh, Haryana, West Bengal, Maharashtra, Himachal Pradesh and Punjab (Tiwari and Agarwal, 2014). In India it is grown in about 447000 hectare with an annual production of 314000 tonnes and productivity 7.02 quintals per hectare in the year 2013-14. In Himachal Pradesh area under coriander is 140 hectare with annual 
production of 50 tonnes (Saxena, 2015). Around 14.5 million tonnes coriander seed was exported in the year 2013-14 with net returns of 37185.65 lakhs US \$ (Anonymous, 2016).

The entire plant of coriander is used as appetizer in preparing fresh chutneys and sauces, and leaves are used for flavouring curries and soup. The fruits are extensively used as condiment preparation of curry powder, pickling spices, seasoning and flavouring of bakery products. These are considered to have carminative, diuretic, tonic, stomachic, antibilious, refrigerant and aprodisiac properties. It contains antioxidants, which can prevent the spoilage of food seasoned with this spice. It is a tropical crop and can be grown throughout the year except very hot season i.e. March-May for leaf purpose, but for higher grain yield it has to be grown in specific season. A dry and cold weather free from frost especially during flowering and fruit setting stage, favours good grain production.

\section{Materials and Methods}

On farm trial conducted on "Studies on effect of cutting and intra row spacing on leaf and seed yield of coriander (Coriandrum sativum L.) was carried out at Dr. YSPUHF, Nauni, Solan (HP) during Rabi 2015-16 i.e. from October, 2015 to April, 2016. The climate is generally characterized as sub-humid, subtemperate with cool winters. Generally, May and June are the hottest months and December and January are the coldest ones. The soil structure of the experimental farm is gravelly loam to gravelly clay loam with $\mathrm{pH}, \mathrm{EC}$ and OC values ranging from 6.85-7.09, 0.60-0.80 $\mathrm{dSm}^{-1}$ and $0.80-0.92 \%$, respectively. Coriander cultivar 'Solan-Selection', a variety with tender leaves and good aroma was used for the present study. The experiment was laid out in a RCBD (Factorial) comprising of 15 treatment combinations of different cutting and intra row spacing (Table 1) with three replications of each treatment. Coriander seeds were directly sown in the field in the month of October, 2015, in a plot of size $1.8 \times 1.5 \mathrm{~m}$ $\left(2.7 \mathrm{~m}^{2}\right.$ area) accommodating 60, 30, 20, 15 and 12 plants per row at spacing of $30 \times 2.5$ $\mathrm{cm}, 30 \times 5.0 \mathrm{~cm}, 30 \times 7.5 \mathrm{~cm}, 30 \times 10.0 \mathrm{~cm}$ and $30 \times 12.5 \mathrm{~cm}$, respectively.

\section{Results and Discussion}

The results revealed that two cuttings $\left(\mathrm{C}_{2}\right)$ resulted in significantly more leaf yield per hectare $\left(30.88\right.$ q) than one cutting $\left(\mathrm{C}_{1}\right)$. However, spacing $S_{1}$ recorded higher leaf yield per hectare $(41.39$ q) compare to other spacing's. Whereas highest leaf yield per hectare $(55.53 \mathrm{q})$ recorded in treatment combination of $\mathrm{C}_{2} \times \mathrm{S}_{1}$. The obvious reason for more leaf yield at two cuttings $\left(\mathrm{C}_{2}\right)$ may be attributed to better vegetative growth of the crop after one cutting $\left(C_{1}\right)$. The results are in line with the findings of Cuba and Debnath (2013) \& Datta et al., (2008). Whereas, Nandal et al., (2007) also reported the higher leaf yield in fenugreek with spacing of $(20 \times$ $10 \mathrm{~cm})$ and two cutting. One cutting $\left(\mathrm{C}_{1}\right)$ resulted in significantly higher seed yield per hectare (17.18 q) and Spacing $\mathrm{S}_{3}$ gave the significantly maximum seed yield per hectare (17.93 q). The interaction between $\mathrm{C}_{1} \times \mathrm{S}_{3}$ gave the highest seed yield per hectare (19.98 q). The results were in line with the findings of Moniruzzaman and Rahman (2015) and Cuba and Debnath (2013) who reported that the highest seed yield was noted with one cutting. Whereas, Sharma et al., (2016) who reported that the medium spacing gave higher seed yield than wider spacing. Maheriya et al., (2015) also reported higher seed yield with one cutting and medium spacing. Highest plant height $(102.95 \mathrm{~cm})$ was recorded with no cutting $\left(\mathrm{C}_{0}\right)$. Widest spacing $\mathrm{S}_{5}$ gave highest plant height $(102.55 \mathrm{~cm})$. The interaction between $\mathrm{C}_{0} \times \mathrm{S}_{5}$ gave the highest plant height $(105.55 \mathrm{~cm})$. The results were in line with those of Tehlan and Thakral (2008) who 
reported that the increasing number of leaf cuttings from one to two drastically reduced the plant height. Whereas, Sharma et al., (2016), Vasmate et al., (2008) and Okut and Yidirim (2005) who observed that the plant height of coriander was increased with wider spacing. Maximum number of primary branches per plant (5.00) was observed with one cutting $\left(\mathrm{C}_{1}\right)$. The significantly maximum number of primary branches per plant (5.52) was recorded with the spacing $\mathrm{S}_{5}$. The interaction between $\mathrm{C}_{1} \times \mathrm{S}_{5}$ gave the maximum number of primary branches per plant (6.66). This result corroborated the findings of Maheriya et al., (2015) who reported that one cutting at 45 DAS recorded significantly highest number of branches per plant. Similar results were also reported by Tehlan and Thakral (2008). Whereas, Tuncturk (2011), Vasmate et al., (2008) and Pawar et al., (2007) who stated that the number of primary branches significantly increased with increasing row spacing. Maheriya et al., (2015) also reported that one cutting at 45 days after sowing at a spacing of $45 \mathrm{~cm}$ recorded significantly highest number of branches per plant. The significantly maximum number of secondary branches per plant (13.00) was observed with one cutting $\left(\mathrm{C}_{1}\right)$.

The significantly maximum number of secondary branches per plant (13.52) were recorded with the spacing $S_{5}$. The interaction between $\mathrm{C}_{1} \times \mathrm{S}_{5}$ gave the maximum number of secondary branches per plant (15.66). Maheriya et al., (2015) who stated that one cutting at 45 DAS recorded significantly highest number of branches per plant. The results were in line with the observations by Tuncturk (2011) and Vasmate et al., (2008) who stated that the number of secondary branches significantly increased with increasing row spacing. Maheriya et al., (2015) also reported that one cutting at 45 days after sowing at a spacing of $45 \mathrm{~cm}$ recorded significantly highest number of branches per plant.

From the present investigation, it can be concluded that the coriander cv. Solan Selection, sown at closer spacing $30 \times 2.5 \mathrm{~cm}$ and left for seed production after two cuttings (60 and 75 DAS) gave the highest leaf yield i.e. $55.53 \mathrm{q} / \mathrm{ha}$ along with seed yield of 17.44 $\mathrm{q} /$ ha with the maximum $\mathrm{B}: \mathrm{C}$ ratio $(3.39: 1)$, whereas, sowing at spacing $30 \times 7.5 \mathrm{~cm}$ and taking seed crop after one cutting (60 DAS) gave the highest seed yield ie $19.98 \mathrm{q} / \mathrm{ha}$ along with leaf yield of $13.28 \mathrm{q} / \mathrm{ha}$ with $\mathrm{B}: \mathrm{C}$ ratio $(2.28: 1)$. Therefore, when green leaf yield is the primary objective, the crop should be sown at closer spacing of $30 \times 2.5 \mathrm{~cm}$ and left for seed production after two cuttings (60 and 75 DAS) for getting maximum financial benefits, whereas, in case of seed yield being the primary objective, sowing at spacing $30 \times 7.5$ $\mathrm{cm}$ and taking seed crop after one cutting (60 DAS) is beneficial under mid hill conditions of Himachal Pradesh.

Table.1 Details of cutting (C) and intra row spacing (S) treatments undertaken during the study

\begin{tabular}{|c|c|}
\hline C: Cutting & S: Spacing \\
\cline { 2 - 2 } & $\mathbf{S}_{\mathbf{1}}: 30 \times 2.5 \mathrm{~cm}$ \\
\hline $\mathbf{C}_{\mathbf{0}}$ : No cutting & $\mathbf{S}_{\mathbf{2}}: 30 \times 5.0 \mathrm{~cm}$ \\
\hline $\mathbf{C}_{\mathbf{1}}:$ One cutting (60 DAS) & $\mathbf{S}_{\mathbf{3}}: 30 \times 7.5 \mathrm{~cm}$ \\
\hline $\mathbf{C}_{\mathbf{2}}:$ Two cuttings $(60 \& 75$ DAS) & $\mathbf{S}_{\mathbf{4}}: 30 \times 10.0 \mathrm{~cm}$ \\
\hline
\end{tabular}


Table.2-Effect of cutting and intra row spacing on yield and morphological traits of coriander

\begin{tabular}{|c|c|c|c|c|c|}
\hline Treatments & $\begin{array}{c}\text { Leaf yield/ha } \\
\text { (q) }\end{array}$ & $\begin{array}{c}\text { Seed yield/ha } \\
(q)\end{array}$ & $\begin{array}{c}\text { Plant Height } \\
\text { (Cm) }\end{array}$ & \begin{tabular}{|c|} 
No. of \\
Primary \\
Branches
\end{tabular} & $\begin{array}{c}\text { No. of } \\
\text { Secondary } \\
\text { Branches }\end{array}$ \\
\hline \multicolumn{6}{|c|}{ Cutting (S) } \\
\hline $\mathrm{C}_{0}:$ No cutting & - & 15.82 & 102.95 & 2.71 & 8.89 \\
\hline $\mathrm{C}_{1}$ :One cutting at $\left.60 \mathrm{DAS}\right)$ & 15.27 & 17.18 & 98.97 & 5.00 & 13.00 \\
\hline $\mathrm{C}_{2}$ :Two cuttings $\left(\begin{array}{lll}60 & \& & 75\end{array}\right.$ & 30.88 & 15.21 & 95.97 & 4.37 & 11.57 \\
\hline $\mathrm{CD}_{(0.05)}$ & 0.60 & 0.84 & 0.74 & 0.26 & 0.23 \\
\hline CV & 52.36 & 6.28 & 3.53 & 29.40 & 18.72 \\
\hline \multicolumn{6}{|c|}{ Intra row Spacing $(\mathbf{S})$} \\
\hline $\mathrm{S}_{1}: 30 \times 2.5 \mathrm{~cm}$ & 41.39 & 16.52 & 95.37 & 2.29 & 9.00 \\
\hline$S_{2}: 30 \times 5.0 \mathrm{~cm}$ & 28.94 & 17.05 & 97.77 & 3.48 & 10.00 \\
\hline$S_{3}: 30 \times 7.5 \mathrm{~cm}$ & 18.32 & 17.93 & 99.70 & 4.11 & 11.14 \\
\hline$S_{4}: 30 \times 10.0 \mathrm{~cm}$ & 14.41 & 15.72 & 101.11 & 4.74 & 12.11 \\
\hline$S_{5}: 30 \times 12.5 \mathrm{~cm}$ & 12.30 & 13.15 & 102.55 & 5.52 & 13.52 \\
\hline $\mathrm{CD}_{(0.05)}$ & 0.94 & 1.08 & 0.96 & 0.34 & 0.29 \\
\hline $\mathrm{CV}$ & 47.85 & 11.33 & 2.84 & 30.51 & 15.84 \\
\hline \multicolumn{6}{|c|}{ Treatment combinations } \\
\hline $\mathbf{C}_{\mathbf{0}} \mathbf{S}_{\mathbf{1}}$ & - & 14.82 & 100.44 & 1.66 & 7.33 \\
\hline $\mathrm{C}_{0} \mathrm{~S}_{2}$ & - & 17.86 & 102.00 & 2.22 & 8.00 \\
\hline $\mathrm{C}_{\mathbf{0}} \mathbf{S}_{\mathbf{3}}$ & - & 17.41 & 102.77 & 2.33 & 8.89 \\
\hline $\mathrm{C}_{\mathbf{0}} \mathrm{S}_{4}$ & - & 15.63 & 104.00 & 3.33 & 9.22 \\
\hline $\mathrm{C}_{0} \mathrm{~S}_{5}$ & - & 13.39 & 105.55 & 4.00 & 11.00 \\
\hline $\mathbf{C}_{1} \mathbf{S}_{1}$ & 27.25 & 17.28 & 95.11 & 2.66 & 10.44 \\
\hline $\mathbf{C}_{1} \mathbf{S}_{2}$ & 17.13 & 18.05 & 97.44 & 4.33 & 11.44 \\
\hline $\mathbf{C}_{\mathbf{1}} \mathbf{S}_{3}$ & 13.28 & 19.98 & 99.11 & 5.44 & 12.89 \\
\hline $\mathbf{C}_{1} \mathbf{S}_{4}$ & 09.91 & 16.79 & 100.77 & 5.89 & 14.55 \\
\hline $\mathrm{C}_{1} \mathrm{~S}_{5}$ & 08.77 & 13.82 & 102.44 & 6.66 & 15.66 \\
\hline $\mathrm{C}_{2} \mathrm{~S}_{1}$ & 55.53 & 17.44 & 90.55 & 2.55 & 9.22 \\
\hline $\mathbf{C}_{2} \mathbf{S}_{2}$ & 40.76 & 15.25 & 93.88 & 3.89 & 10.55 \\
\hline $\mathrm{C}_{2} \mathrm{~S}_{3}$ & 23.36 & 16.40 & 97.22 & 4.55 & 11.66 \\
\hline $\mathrm{C}_{2} \mathrm{~S}_{4}$ & 18.90 & 14.73 & 98.55 & 5.00 & 12.55 \\
\hline $\mathrm{C}_{2} \mathrm{~S}_{5}$ & 15.83 & 12.24 & 99.66 & 5.89 & 13.89 \\
\hline $\mathrm{CD}_{(0.05)}$ & 1.33 & 1.87 & 1.66 & 0.59 & 0.51 \\
\hline CV & 58.45 & 12.80 & 4.04 & 38.39 & 21.80 \\
\hline
\end{tabular}


Table.4.4 Economics of different cutting and intra row spacing treatments in coriander

\begin{tabular}{|c|c|c|c|c|c|c|c|c|}
\hline Treatments & $\begin{array}{l}\text { Leaf yield } \\
\text { per hectare } \\
\text { (q) }\end{array}$ & $\begin{array}{l}\text { Seed yield } \\
\text { per hectare } \\
\text { (q) }\end{array}$ & $\begin{array}{c}\text { Income from leaf } \\
\text { @ Rs 3000/q (Rs } \\
\left.\text { ha }^{-1}\right)\end{array}$ & $\begin{array}{c}\text { Income from seed } \\
\text { @ Rs 10000/q (Rs } \\
\left.\text { ha }^{-1}\right)\end{array}$ & $\begin{array}{l}\text { Gross income } \\
\left(\mathrm{Rs} \mathrm{ha}^{-1}\right)\end{array}$ & $\begin{array}{c}\text { Cost of cultivation } \\
\left(\mathrm{Rs} \mathrm{ha}^{-1}\right)\end{array}$ & $\begin{array}{l}\text { Net return } \\
\left(\operatorname{Rs~ha}^{-1}\right)\end{array}$ & B:C ratio \\
\hline $\mathrm{C}_{0} \times \mathrm{S}_{1}$ & 0 & 14.82 & 0 & 148200.00 & 148200.00 & 68260.08 & 79939.92 & 1.17 \\
\hline $\mathrm{C}_{0} \times \mathrm{S}_{2}$ & 0 & 17.86 & 0 & 178600.00 & 178600.00 & 68260.08 & 110339.92 & 1.62 \\
\hline $\mathrm{C}_{\mathbf{0}} \times \mathrm{S}_{3}$ & 0 & 17.41 & 0 & 174100.00 & 174100.00 & 68260.08 & 105839.92 & 1.55 \\
\hline $\mathrm{C}_{0} \times \mathrm{S}_{4}$ & 0 & 15.63 & 0 & 156300.00 & 156300.00 & 68260.08 & 88039.92 & 1.29 \\
\hline $\mathrm{C}_{0} \times \mathrm{S}_{5}$ & 0 & 13.39 & 0 & 133900.00 & 133900.00 & 68260.08 & 65639.92 & 0.96 \\
\hline $\mathrm{C}_{1} \times \mathrm{S}_{1}$ & 27.25 & 17.28 & 81750.00 & 172800.00 & 254550.00 & 72952.08 & 181597.92 & 2.49 \\
\hline $\mathrm{C}_{1} \times \mathrm{S}_{2}$ & 17.13 & 18.05 & 51390.00 & 180500.00 & 231890.00 & 72952.08 & 158937.92 & 2.18 \\
\hline $\mathrm{C}_{1} \times \mathrm{S}_{3}$ & 13.28 & 19.98 & 39840.00 & 199800.00 & 239640.00 & 72952.08 & 166687.92 & 2.28 \\
\hline $\mathrm{C}_{1} \times \mathrm{S}_{4}$ & 9.91 & 16.79 & 29730.00 & 167900.00 & 197630.00 & 72952.08 & 124677.92 & 1.71 \\
\hline$C_{1} \times S_{5}$ & 8.77 & 13.82 & 26310.00 & 138200.00 & 164510.00 & 72952.08 & 91557.92 & 1.26 \\
\hline $\mathrm{C}_{2} \times \mathrm{S}_{1}$ & 55.53 & 17.44 & 166590.00 & 174400.00 & 340990.00 & 77644.08 & 263345.92 & 3.39 \\
\hline $\mathrm{C}_{2} \times \mathrm{S}_{2}$ & 40.76 & 15.25 & 122280.00 & 152500.00 & 274780.00 & 77644.08 & 197135.92 & 2.54 \\
\hline $\mathrm{C}_{2} \times \mathrm{S}_{3}$ & 23.36 & 16.40 & 70080.00 & 164000.00 & 234080.00 & 77644.08 & 156435.92 & 2.01 \\
\hline $\mathbf{C}_{2} \times \mathbf{S}_{4}$ & 18.90 & 14.73 & 56700.00 & 147300.00 & 204000.00 & 77644.08 & 126355.92 & 1.63 \\
\hline $\mathrm{C}_{2} \times \mathrm{S}_{5}$ & 15.83 & 12.24 & 47490.00 & 122400.00 & 169890.00 & 77644.08 & 92245.92 & 1.19 \\
\hline
\end{tabular}




\section{Acknowledgments}

The authors deeply acknowledge Dr. Happy Dev Sharma (Principal Scientist) \& Dr. Vipin Sharma (Assistant Professor) from Dr. YS Parmar UHF, Solan (HP) who had supported in this research work.

\section{References}

Anonymous. 2016. Spice Board of India. http://indianspices.in $\left[10.30 \mathrm{PM}, 20^{\text {th }}\right.$ June 2017]

Cuba S, Sharangi AB and Debnath S. 2013. Effect of different sowing times and cutting management on phenology and yield of off season coriander under protected cultivation. Trends in Horticulture Research 3:27-32.

Datta S, Alam K and Chatterjee R. 2008. Effect of different level of nitrogen and leaf cutting on growth, leaf and seed yield of coriander. Indian Journal of Horticulture 64:201-03.

Maheriya VD, Patel HF and Makvana AI. 2015. Effect of cutting management, nitrogen and spacing on green leaf yield and grain yield of coriander (Coriander sativum L) cv 'Guj. Cori-2'. Trends in Biosciences 8:1849-52.

Moniruzzaman M and Rahman MM. 2015. Effect of nitrogen level and leaf cutting frequency on foliage and seed yields of coriander. Bangladesh Journal of Agricultural Research 40:53-60.

Nandal JK, Dahiya MS, Gupta V and Singh D. 2007. Response of sowing time, spacing and cutting of leaves on growth and seed yield of fenugreek. Haryana Journal of Horticultural Sciences 36:374-76.

Okut $\mathrm{N}$ and Yidirim B. 2005. Effect of different row spacing and nitrogen doses on certain agronomic characteristics of coriander (Coriandrum sativum L). Pakistan Journal of Biological Sciences 8:90104.

Pawar PM, Naik DM, Damodhar VP, Shinde VN and Bhalerao RV. 2007. Influence of graded levels of spacing and nitrogen on growth and yield of coriander (Coriandrum sativum L). Asian Journal of Horticulture 2:58-60.

Saxena M. Horticultural statistical at a glance 2015. http://nhb.gov.in [10.45 PM, 20 ${ }^{\text {th }}$ June 2017]

Sharma A, Naruka IS and Shaktawat RPS. 2016. Effect of row spacing and nitrogen on growth and yield of coriander (Coriandrum sativum L). Journal of Krishi Vigyan 5:49-50.

Tehlan SK and Thakral KK. 2008. Effect of different level of nitrogen and leaf cutting on leaf yield of coriander (Coriandrum sativum L). Journal of Spices and Aromatic Crops 17:180-82.

Tiwari RS and Agarwal A. 2014. Production Technology of Spices. $2^{\text {nd }}$ ed. International Book Distribution Company, New Delhi, India. 254-71pp.

Tuncturk R. 2011. Effects of different row spacings on the yield and quality in coriander (Coriandrum sativum L) cultivars. International Journal of Food and Agricultural Economics 21:89-97.

\section{How to cite this article:}

Pradip Balaso Bhapkar, H Dev Sharma, Sudhaker Negi, Diksha Pundir, Vipin Sharma, Monika Kapil and Sridhar Reddy. 2019. Effect of Cutting and Intra Row Spacing on Yield and Phenotypical Attributes of Coriander (Coriandrum sativum L.). Int.J.Curr.Microbiol.App.Sci. 8(09): 693-698. doi: https://doi.org/10.20546/ijcmas.2019.809.083 